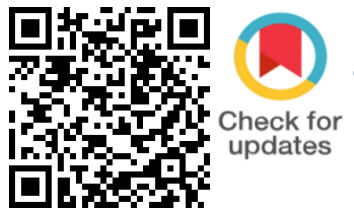

\title{
Plants used for Piles Treatment in Shivamogga District, Karnataka
}

\author{
Veeranna B Shettar ${ }^{1} \mid$ Ranjith $\mathrm{Y}^{2} \mid$ Arunakumar N C \\ ${ }^{1}$ Lecturer, Department of Botany, SJVP College, Davangere University, Harihar \\ ${ }^{2}$ Lecturer, Department of Botany, Sahyadri Science College, Kuvempu University, Shivamogga \\ ${ }^{3}$ Assistant Professor, Department of Chemistry, Sahyadri Science College, Kuvempu University, Shivamogga
}

To Cite this Article

Veeranna B Shettar, Ranjith Y and Arunakumar N C, "Plants used for Piles Treatment in Shivamogga District, Karnataka", International Journal for Modern Trends in Science and Technology, Vol. 07, Issue 01, January 2021, pp.- 99-101.

Article Info

Received on 28-November-2020, Revised on 21-December-2020, Accepted on 02-January-2021, Published on 11-January-2021.

\section{ABSTRACT}

The present study deals with the documentation of plants used for piles treatment in Shivamogga district of Karnataka. The peoples of this area have a very good knowledge about the treatment of various diseases and piles. Piles are commonly occurring ailment and the peoples treat piles successfully with the help of different plant species found within their area. Every elder peoples of this area have common knowledge and easy cure for many common ailments and prepare different types of medicines from different plant parts. A total of 56 plant species belonging to 54 genera and distributed over 36 families were found to be used by the peoples in the treatment of piles.

KEYWORDS: Plant diversity, Shivamogga district, Piles, Traditional Knowledge

\section{INTRODUCTION}

The information of medicinal plants has been accumulated in the course of many centuries based on different medicinal systems such as Ayurveda, Unani and Siddha. In India it is reported that conventional healers use 2500 plant species and 100 species of plants serve as regular sources of medicine (Pei, 2001). In recent years, there has been a remarkable range of interest in the medicinal plants especially those used in traditional systems of medicines. Medicines obtained from the plant are believed to be much safer and exhibit a remarkable efficacy in the treatment of various ailments (Siddiqui, et.al. 1995). The folk medicinal traditions play a reflecting and prominent role in human and environment interaction (Chopra, et.al.1956). It is estimated that 70 to $80 \%$ of the people worldwide depends chiefly on traditional health care system andlargely on herbal medicines (Farnsworth et.al. 1985, 1991, Shengii 2002, Shanley, et.al. 2003; Hiremath et al.,2010). The aim of the present study is to know the variety of plants used for piles treatment in Shivamogga district of Karnataka.

\section{Materials AND Methods}

Shivamogga district is a district in the Karnataka state of India (Figure1). A major part of Shivamogga district lies in the Malnadregion of the Western Ghats. Shivamogga city is its administrative centre. Shivamogga district is a part of the malnad region of Karnataka and is also known as the 'Gateway to Malnad' or 'MalenaadaHebbagilu' in Kannada. The district ranks 9th in terms of the total area among the districts of Karnataka. It is 
spread over an area of $8465 \mathrm{~km} 2$ (National Informatics Centre,2007). Shivamogga lies between the latitudes $13^{\circ} 27^{\prime}$ and $14^{\circ} 39^{\prime} \mathrm{N}$ and between the longitudes $74^{\circ} 38^{\prime}$ and $76^{\circ} 04^{\prime} \mathrm{E}$ at a mean altitude of 640 metres above sea level (National Informatics Centre,2007). The peak Kodachadri hill at an altitude of 1343 metres above sea level is the highest point in this district.

The present study is an attempt to know the documentation of plants used for piles treatment in Shivamogga district of Karnataka. Local traditional healers for treating piles were often visiting the areas of the district to collect plant species. Periodic field survey were carried out during July 2017 to December 2017. Data were collected through local herbal practitioner, village elders and native medicine men residing around Shivamogga areas through personal communication. Standard methods were followed for the collection of plant materials and preservation of plant species. Voucher specimens were collected, identified, by referring standard flora (Hooker, 1884; Gamble ,1936; and Saldhana, 1984).

\section{RESULTS AND DISCUSSION}

A total of 56 plant species used especially for the treatment of Piles by the communities of Shivamogga District, Karnataka. These plants belongings to 54 genera comprising of 36 families. The different parts of the plants used for piles treatment is shown in Table 1 . They had been cross checked by literature previously reported for Piles.

Among the different plant parts, the fruits, bulb, seed, rhizome, leaf, whole plant parts, root/ bark etc are used for piles treatment. The methods of preparation fall into 4 categories viz., plant parts used as a paste, juice from the fresh plant parts, powder from fresh or dried plant parts and in the form of decoction. External applications and the internal consumption of the preparations involved in the treatment of piles. The conventional knowledge about utilization of local plant species is vital in alternate healthcare system as well as for the self sustenance of local population. High costs coupled with numerous side effects of synthetic drugs are forcing people to depend on the locally available herbal medicine for their healthcare needs. Methods of medical treatment used by knowledgeable elder people and local herbal healers in Shivamoggataluk were totally traditional, very effective and acquired through their ancestors orally. It is high time that these herbal species are scientifically evaluated and conserved for the well being of mankind. These traditional herbal formulations need further pharmacological investigations to prove their efficacy and also develop new drugs for the effective treatment of chronic diseases (Shivanna\& Rajakumar, 2010).

\section{Conclusion}

The present study documented the plants used in the treatment of piles by the people of Shivamogga district, Karnataka. This study can serve as baseline information on the medicinal plants prosperity of this area. Further study will throw more light about the vast wealth of ethnobotanical information. Further pharmacological and clinical studies on these plants will provide effective natural medicines for piles treatment and it will also be useful to determine in the bio-prospecting potential of these plants.

\section{REFERENCES}

[1] Hiremath,V.T.,M.M.J. Vijaykumar and T.C. Taranath. 2010. Survey on Ethno- medicinal Plants of Jogimatti Forest Chitradurga District, Karnataka, India. Environ. We Int. J. Sci. Tech. 5 :223-233.

[2] Hooker 1978. Flora of British India, Vol.1-7. Dehra Dun: Bishan Singh Mahendrapal Singh.

[3] National Informatics Centre. "Geography of Shivamogga". The Official website of Shimoga District. District Administration, Shimoga. Retrieved 2007-03-25.

[4] Pei,2001.Ethnobotanical approaches of traditional medicine studies some experiences from Asia, Pharma Bio 39, 74-79.

[5] Rameshkumar, S and Ramakritinan C.M.2013. Floristic survey of traditional herbal medicinal plants for treatments of various diseases from coastal diversity in Pudhukkottai District, Tamilnadu, India . Journal of Coastal Life Medicine 1(3): 225-232.

[6] Saldanha,1984.Flora of Karnataka. New Delhi: Oxford and IBH Publishing Co.1984.

[7] Shanley, and Luz, 2003. The impacts of forest degradation on medicinal plant use and implication for health care in Eastern Amazonia. Bio Science, 53 (6), 573 - 584.

[8] Shivanna, M.B \& N Rajakumar.2010. Ethno-medico-botanical knowledge of rural folk in Bhadravathitaluk of Shivamogga district, Karnataka. Indian Journal of Traditional Knowledge Vol. 9 (1), January 2010, pp. 158-162.

[9] Siddiqui, M.A.A., John, A.Q., Paul, T.M.,1995. Status of some important medicinal and aromatic plants of Kashmir Himalaya. Advances in Plant Sciences, 8, 134-139.

[10] ThiyamTomba Singh, HanjabamManoranjan Sharma, AnoubamRadhapyari Devi, HanjabamRajanikanta Sharma. Plants Used in the Treatment of Piles by the Scheduled Caste Community of Andro Village in Imphal East District, Manipur (India). Journal of Plant Sciences. Vol. 2, No. 3, 2014, pp. 113- 119 . doi: $10.11648 /$ j.jps.20140203.13.

[11] WHO. WHO traditional medicine strategy. Geneva: World Health Organization; 2002. (Online) Available at:http://www.who.int/edicines/publications/traditional policy/en/. (Access on 23 April, 2013). 
Table 1: List of plants used for piles treatment in Shivamogga district, Karnataka

\begin{tabular}{|c|c|c|c|}
\hline S1.No & Scientific name & Family & Parts used \\
\hline 1. & Azadirachthaindica & Meliaceae & Leaf, seed \\
\hline 2. & Allium cepa & Amaryllidaceae & Bulb \\
\hline 3. & Aloe vera & Asphodelaceae & Root \\
\hline 4. & Abutilon indicum & Malvaceae & Leaf,Root \\
\hline 5. & Achyranthusaspera & Amaranthaceae & Whole plant \\
\hline 6. & Aeglemarmelos & Rutaceae & Whole plant \\
\hline 7. & Buteamonosperma & Fabaceae & Bark \\
\hline 8. & Carica papaya & Caricaceae & Fruit \\
\hline 9. & Citrus limonum & Rutaceae & Fruit \\
\hline 10. & Centellaasiatica & Apiaceae & Leaf \\
\hline 11. & Coriandrumsativum & Apiaceae & Leaf, Seed \\
\hline 12. & Calotropisprocera & Apocynaceae & Root \\
\hline 13. & Cocosnucifera & Arecaceae & Fruit \\
\hline 14. & Cyperusrotundus & Cyperaceae & Root \\
\hline 15. & Cynodondactylon & Poaceae & Whole plant \\
\hline 16. & Cassia fistula & Fabaceae & Bark \\
\hline 17. & Euphorbia hirta & Euphorbiaceae & Whole plant \\
\hline 18. & Eucalyptus globulus & Myrtaceae & Leaf \\
\hline 19. & Eclipta alba & Asteraceae & Leaf \\
\hline 20. & Ficusbenghalensis & Moraceae & Bark \\
\hline 21. & Ficusreligiosa & Moraceae & Bark \\
\hline 22. & Gloriosasuperba & Colchicaceae & Tuber \\
\hline 23. & Hemidesmusindicus & Apocynaceae & Leaf \\
\hline 24. & Hibiscus rosasinensis & Malvaceae & Leaf \\
\hline 25. & Ipomea sp. & Convolvulaceae & Whole plant \\
\hline 26. & Jatrophacurcus & Euphorbiaceae & Leaf \\
\hline 27. & Jasminummultiflorum & Oleaceae & Flower \\
\hline 28. & Leucasaspera & Lamiaceae & Leaf \\
\hline 29. & Lantana camara & Verbenaceae & Leaf,Shoot \\
\hline 30. & Mimosa pudica & Fabaceae & Whole plant \\
\hline 31. & Mangiferaindica & Anacardiaceae & Seed, Bark \\
\hline 32. & Momordicacharantia & Cucurbitaceae & Fruit \\
\hline 33. & Moringaoleifera & Moringaceae & Leaf, Root \\
\hline 34. & Musa sp. & Musaceae & Fruit \\
\hline 35. & Millettiapinnata & Fabaceae & Leaf \\
\hline 36. & Nelumbonucifera & Nelumbonaceae & Whole plant \\
\hline 37. & Neriumindicum & Apocynaceae & Flower \\
\hline 38. & Ocimumbassilicum & Lamiaceae & Leaf \\
\hline 39. & Oxalis corniculata & Oxalidaceae & Whole plant \\
\hline 40. & Phyllanthusemblica & Phyllanthaceae & Fruit \\
\hline 41. & Psidiumguajava & Myrtaceae & Fruit \\
\hline 42. & Piper nigrum & Piperaceae & Fruit \\
\hline 43. & Punicagranatum & Lythraceae & Fruit \\
\hline 44. & Raphanussativus & Brassicaceae & Whole plant \\
\hline 45. & Solanumnigrum & Solanaceae & Fruit \\
\hline 46. & Saracaindica & Fabaceae & Bark \\
\hline 47. & Syzygiumcumini & Myrtaceae & Fruit \\
\hline 48. & Terminaliachebula & Combretaceae & Leaf \\
\hline 49. & Terminaliabellerica & Combretaceae & Leaf \\
\hline 50. & Tinosporacordifolia & Menispermaceae & Root \\
\hline 51. & Tagetessp & Asteraceae & Bud \\
\hline 52. & Tamarindusindica & Fabaceae & Root \\
\hline
\end{tabular}

